Gundars Bērziņš, Jānis Priede

\title{
Inovāciju izaicinājumi Latvijā salīdzinājumā ar citām Eiropas Savienības valstīm
}

Stabila ekonomikas izaugsme nav iespējama bez inovācijām. Savukārt galvenie stūrakmeņi, kas balsta inovācijas, ir:

- cilvēku resursi (pētnieki un inženieri);

- investīcijas (pētniecībā, attīstībā un inovācijās);

- infrastruktūra (materiāli tehniskā bāze, kas piemērota tehnolog̣iju un produktu izstrādei, pārnesei un inovācijām);

- specializācija, kooperācija un starptautiskā sadarbība.

Kā vairākkārt norādījusi ES Padome un EK, Latvija maz iegulda P\&A un tai ir ievērojams investīciju deficīts inovācijas jomā. 2019. gadā P\&A paredzēto Latvijas izdevumu ipatsvars bija viens no zemākajiem ES ${ }^{1}$, un pēdējo desmit gadu laikā šis rādītājs būtiski nav mainījies. Latvijai tiek rekomendèts uz ieguldījumiem vērsto ekonomikas politiku koncentrēt uz inovācijām.

Valstu izaugsmes un konkurētspējas jautājums, kas tiešā veidā korelē ar inovācijām, ir vienmēr bijis aktuāls, un šā jautājuma nozīme nav mainījusies arī Covid-19 apstākḷıs. Analizējot būtiskākās valstu konkurētspējas komponentes, ir vērts ieskatīties analītiskos pētījumos, kuros ir uzsvērta inovāciju nozīmība valstu konkurētspējas veicināšanā.

1 Eurostat. GERD by sector of performance. Pieejams: https://ec.europa.eu/eurostat/databrowser/view/RD_E_GERDTOT__custom_428698/default/table?lang=en [skatīts 09.12.2020.] 


\section{Latvijas inovāciju snieguma kvantitatīvi novērtējumi}

Latvijas inovāciju sniegums ir vērtēts ne vienā vien pētījumā. Šajā pētījumā atsaucamies uz Pasaules Ekonomikas foruma veidoto "Globālo konkurētspējas ziņojumu”2, EK "Eiropas Inovāciju pārskatu”, Pasaules intelektuālā īpašuma organizācijas "Globālo Inovāciju indeksu" (GII) ${ }^{4}$ un "Bloomberg Inovāciju indek-

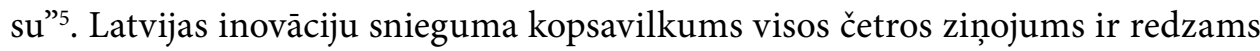
1. attēlā.

Sāksim ar Pasaules Ekonomikas foruma ziņojumu (World Economic Forum, 2019). ${ }^{6}$ Būtiski pieminēt, ka Pasaules Ekonomikas foruma ziṇojumi balstās uz metodologiju, kas ik pa laikam tiek modernizēta, un 2018. gadā ziņojums balstījās jau uz ceturto metodoloǵijas iterāciju. Saskaṇā ar šo ziṇojumu konkurētspējas metodologijā izdala 12 valsts konkurētspēju nosakošus pīlārus, kas attiecīgi ir sagrupēti četrās kategorijās:

- Veicinošā vide: 1. Institūcijas. 2. Infrastruktūra. 3. IKT adaptācija. 4. Makroekonomiskās stabilitāte.

- Cilvēkkapitāls: 5. Veselība. 6. Prasmes.

- Tirgi: 7. Produktu tirgus. 8. Darba tirgus. 9. Finanšu sistēma. 10. Tirgus lielums.

- Inovāciju ekosistēma: 11. Biznesa dinamisms. 12. Inovācijas spēja (2. attēls).

Tieši 12. pīlārs "Inovācijas spēja" ir viens no būtiskākajiem faktoriem, kas nosaka valsts spēju attīstīt inovācijās balstītu ekonomiku ar augstu pievienoto vērtību. Arī vienkārša korelācija starp inovācijas novērtējumu un radīto vērtību atklāj nozīmīgumu (3. attēls).

Pasaules Ekonomikas foruma metodolog̣ijā “inovācijas spēja” tiek vērtēta mijiedarbība un daudzveidība (darbaspēka daudzveidība, klasteru attīstība, starptautiskie kopizgudrojumi un cita sadarbība), P\&A (zinātniskās publikācijas, patentu pieteikumi, izdevumi P\&A, pētniecības iestāžu sasniegumi) un komercializācija (pircēju vērtējums un preču zīmju pieteikumi). Kā redzams 3. attēlā, ir cieša sakarība starp inovācijas spēju un valstu spēju radīt vērtību. Starp "inovācijas spējas” līderēm ES ir lielvalstis un ziemel̦valstis, savukārt Latvija atrodas vienā

WEF. (2020). Global Competitiveness Report Special Edition 2020: How Countries are Performing on the Road to Recovery. Pieejams: https://www.weforum.org/reports/the-global-competitiveness-report-2020 [skatìts 20.03.2021.]

3 European Commission. (2020). What is the European Innovation Scoreboard? Pieejams: https://ec.europa.eu/commission/presscorner/detail/en/QANDA_20_1150 [skatīts 19.03.2021.]

4 WIPO. Global Innovation Index 2020. Pieejams: https://www.wipo.int/global_innovation_index/ en/2020/ [skatīts 22.03.2021.]

Bloomberg. Pieejams: https://www.bloomberg.com [skatīts 20.03.2021.]

6 WEF. (2019). The Global Competitiveness Report 2019. Pieejams: http://www3.weforum.org/docs/ WEF_TheGlobalCompetitivenessReport2019.pdf [skatits 09.02.2021.] 


\section{1. attēls. Latvijas inovāciju sniegums dažādos valstu inovāciju novērtējuma zinojumos 2019./2020. gadā}

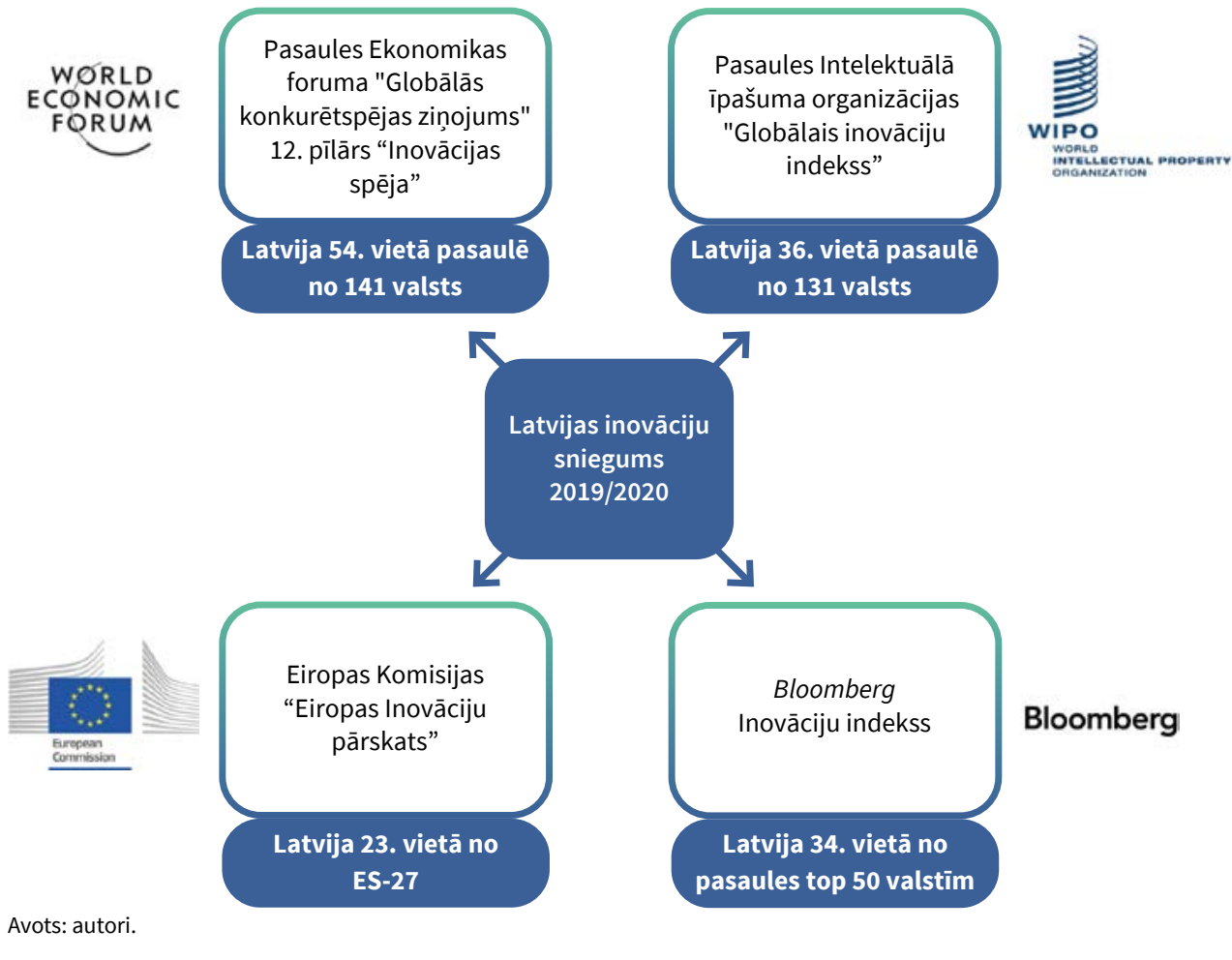

\section{2. attēls. Globālās konkurētspējas indeksa 4.0 ietvars}

\begin{tabular}{|c|c|}
\hline Veicinošā vide & Tirgi \\
\hline 1. Institūcijas & 7. Produktu tirgus \\
\hline 2. Infrastruktūra & 8. Darba tirgus \\
\hline 3. IKT adaptācija & 9. Finanšu sistēma \\
\hline 4. Makroekonomiskā stabilitāte & 10. Tirgus lielums \\
\hline Veicinošā vide & Inovāciju ekosistēma \\
\hline 5. Veselība & 11. Biznesa dinamisms \\
\hline 6. Prasmes & 12. Inovācijas spēja \\
\hline
\end{tabular}




\section{3. attēls. Korelācijas starp Pasaules Ekonomikas foruma inovācijas spējas novērtējumu un reālo IKP uz 1 iedzīvotāju 2019. gadā, EUR}

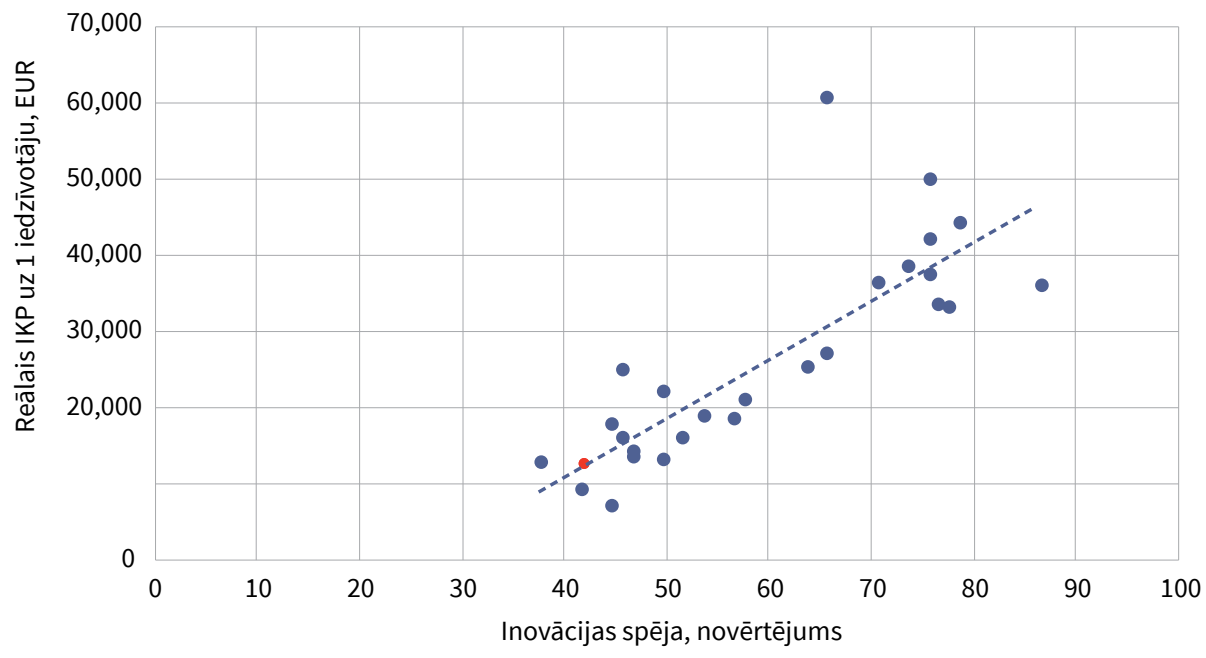

Avoti: World Economic Forum, 2019, Eurostat.

no pēdējām vietām starp ES dalībvalstīm. Lìdzīga aina paveras arī EK veidotajā ziṇojumā par inovācijām ES̄ un Globālajā Inovāciju indeksā.

Bloomberg 2021. gada inovāciju indeksā (Bloomberg 2021 Innovation Index ${ }^{8}$ ) Latvija ierindojas 34. vietā (plus 3 vietas salīdzinājumā ar 2020. gadu). Apskatot detalizētākus rādītājus, Latvija ierindojas 49. vietā P\&A intensitātē, 46. vietā - ražošanas produktu pievienotajā vērtībā, 31. vietā - produktivitātē, 30. vietā - augsto tehnologiju izmantošanā, 6 . vietā - terciārajā intensitātē, 40. vietā - pētnieku pieejamībā, 49. vietā - patentu aktivitātē. Bloomberg Inovāciju indekss ir balstīts uz sešiem vienādi svērtiem rādītājiem. Rādītāji tiek apvienoti, lai katrai valstij nodrošinātu kopējo punktu skaitu no nulles līdz 100.

Bloomberg Inovāciju indeksā tiek ņemti vērā šādi kritēriji:

- P\&A - pētniecības un attīstības izdevumi procentos no IKP.

- Ražošana - ražošanas pievienotā vērtība uz vienu iedzīvotāju.

7 Hollanders, H., Es-Sadik, N., Merkelbach, I., \& Khalilova, A. (2020). European Innovation Scoreboard 2020, (June), 98.

8 BloombergQuint. (2021). South Korea Leads World in Innovation as U.S. Exits Top Ten. Pieejams: https://www.bloombergquint.com/global-economics/south-korea-leads-world-in-innovation-u-sdrops-out-of-top-10 [skatits 06.02.2021.] 
- Augsto tehnologiju uzṇēmumi - vietējo augsto tehnolog̣iju valsts uzṇēmumu skaits kā daḷa no visiem pasaules augsto tehnolog̣iju valsts uzṇēmumiem.

- Pēcvidusskolas izglītība - pēcvidusskolas iestādēs uzṇemto vidusskolas absolventu skaits procentos no kohortas; darbaspēka procentuālā daļa ar augstākās izglīiības grādu; zinātnes un inženierzinātṇu absolventi procentos no darbaspēka un procentos no visiem augstskolu absolventiem.

- Pētniecības personāls - profesionāḷi, tostarp Ph. D. studenti, kas nodarbojas ar pētniecíbu un attīstību, uz 1 miljonu iedzīvotāju.

- Patenti - pastāvīgo iedzīvotāju patentu pieteikumi uz 1 miljonu iedzīvotāju un uz iztērēto 1 miljonu ASV dolāru pētniecībā un attīstībā; piešḳirtie patenti procentos no pasaules kopējā apjoma.

Bloomberg Inovāciju indekss ņem vērā mazāk faktoru, salīdzinot ar GII. GII pievērš lielāku uzmanību kontekstam - tas ietver politisko un regulatīvo vidi, infrastruktūru, tirgus izsmalcinātību un radošumu.

GII (Global Inovation Index 2020) ${ }^{9} 2020$. gadā Latvija ierindota 36. vietā. No Skandināvijas valstīm Dānija atrodas 6. vietā, Zviedrija - 2. vietā, Somija - 7. vietā. No septiṇām rādītāju kategorijām Latvijai vislabākais sniegums bijis radošàs izlaides kategorijā, kur Latvija ien̦em 28. vietu pasaulē. Institūciju kategorijā Latvija ieņem 30. vietu, tirgus attīstības kategorijā - 43. vietu, biznesa attīstībā 41. vietu, cilvēku kapitāla un izpētes kategorijā - 44. vietu, zināšanu un tehnologiju izlaides kategorijā - 42. vietu, infrastruktūras kategorijā - 45. vietu. GII ir ikgadējs ziṇojums, kurā apkopoti valstu/ekonomiku inovācijas veicinošās vides un inovācijas rezultāti. GII aptver 141 ekonomiku visā pasaulē un dažādās jomās izmanto 79 rādītājus. GII 2015 izveidoja Kornela Universitāte, The Business School for world (INSEAD) un Pasaules Intelektuālā īpašuma organizācija (WIPO).

EK publicētajā 2020. gada Eiropas inovāciju pārskatā Latvija ierindota 23. vietā ES dalībvalstu vidū, par vienu vietu augstāk nekā iepriekšējos gados. Latvija ir to valstu vidū, kuras tiek dēvētas par mērenajiem inovatoriem (4. attēls). ${ }^{10}$ Latvijai zemākie rādītāji joprojām saglabājas privātajās investīcijās P\&A, mazajos un vidējos uzñēmumos, kas iekšēji veic inovācijas, un doktora grādu ieguvušo skaita ziņā, tāpēc uzsvērta nozīmība turpināt un attīstīt pasākumus pētniecības, attīstības un inovācijas aktivitātes veicināšanā, tādējādi uzlabojot šos rādītājus. ${ }^{11}$

9 The Global Innovation Index (GII) 2020. Pieejams: https://www.globalinnovationindex.org/Home [skatits 14.03.2021.]

10 Eiropas Komisija. European innovation scoreboard 2020. Pieejams: https://ec.europa.eu/growth/industry/policy/innovation/scoreboards_lv [skatīts 01.02.2021.]

11 LV portāls. (2020). Uzṇēmējdarbības aktivitāte Latvijā - otrā augstākā Eiropā. (Dienaskārtībā, 06.07.2020.) Pieejams: https://lvportals.lv/dienaskartiba/317819-uznemejdarbibas-aktivitate-latvija-otra-augstaka-eiropa-2020 [skatits 01.02.2021.] 


\section{4. attēls. Eiropas Savienības dalībvalstu inovāciju sistēmu snieguma novērtējums} 2020. gadā

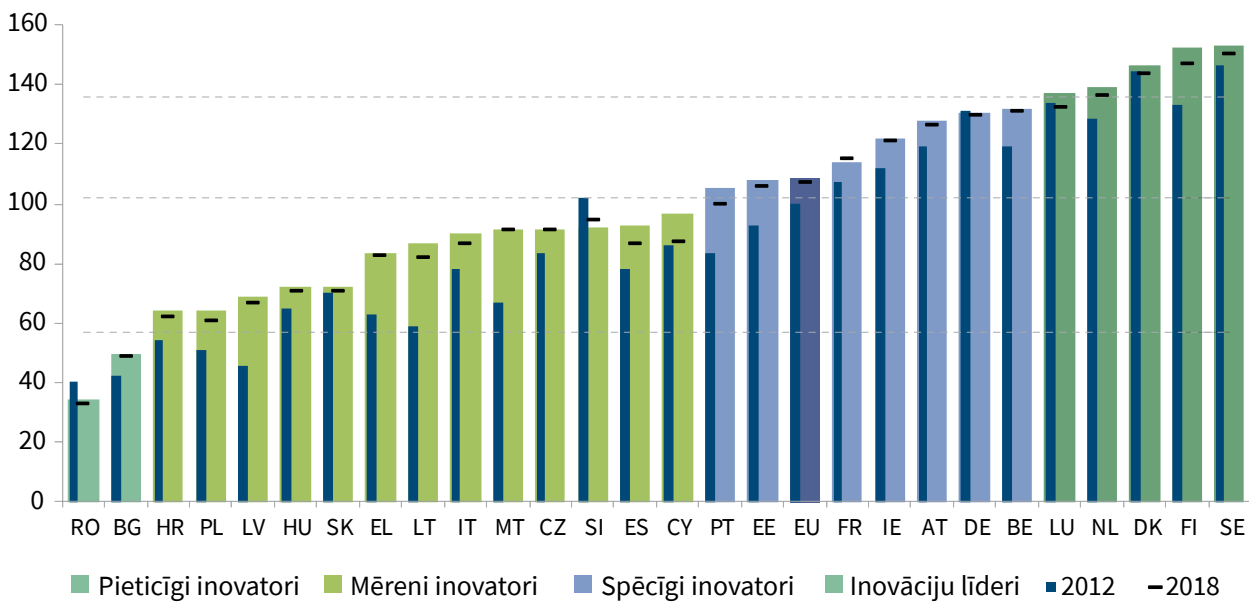

Apskatītie četri ziṇojumi nav vienīgie, kuros vērtēta valstu konkurētspēja un inovācijas spēja, šādu mēgeinājumu radīt alternatīvas metodolog̣ijas ir daudz. Katram apskatītajam valstu inovācijas spējas novērtējumiem ir savas priekšrocības un trūkumi, taču tos nav iespējams kritiski vērtēt vai objektīvi salīdzināt, jo katram ir savs "skatu punkts" un katra metodolog̣ija vairāk izcel kādu atsevišķu jomu. Ja kāda metodologija ietver vairāk rādītāju, tas nenozīmē, ka tā ir labāka, tāpēc salīdzinājumus izdarīt ir sarežgìiti. Zinātniskajā literatūrā ir mēǵinājumi argumentēt un kritizēt ziṇojumu metodologiju, tomēr jāṇem vērā, ka arī metodologija ir dinamiska un pielāgojas izteiktajiem priekšlikumiem, un laika gaitā pilnveidojas, lai iespējami labi atspoguḷotu inovācijas procesu.

\section{Pētniecības un attīstības izaicinājumi Latvijā}

Lai gan P\&A izdevumi nāk gan no sabiedriskā, gan privātā sektora, pētỉjumi uzsver uzņēmumu P\&A būtisko nozīmi zināšanu krājuma palielināšanā un izgudrojumu radīšanā ${ }^{12}$, kā arī patentu izmantošanu, kas ir galvenais intelektuālā ippašuma tiesību aizsardzības līdzeklis, lai pielāgotu P\&A atdevi. Lai gan pētnieki neviennozīmīgi vērtē $P \& A$ izdevumu tiešo ietekmi uz patentu skaitu, norādot

12 Hagedoorn, J., \& Wang, N. (2012). Is there complementarity or substitutability between internal and external R\&D strategies? Research Policy, 41(6), 1072-1083. Pieejams: https://doi.org/10.1016/j. respol.2012.02.012 [skatīts 11.02.2021.] 
uz faktoriem, kas ietekmē jaunu zināšanu radīšanu, piemēram, paša pētniecības procesa vadīšanu ${ }^{13}$, kā arī to, cik lielā mērā intelektuālā īpašuma aizsardzība kavē vai veicina inovācijas un ar to saistītos P\&A izdevumus. ${ }^{14}$ Neraugoties uz sarežgìto pētniecības un inovāciju procesu, pētnieki ir pierādījuši neapšaubāmu sakarību starp izdevumiem P\&A un patentu skaitu, citiem vārdiem sakot, pieejamais finansējums vairo iespējas iegūt jaunas zināšanas, pat neraugoties uz finansējuma izmantošanas efektivitāti. ${ }^{15}$ Vērtējot pēc ieņēmumiem uz vienu darbinieku un vidējām algām, ir pārliecinoša pozitīva saistība starp dažādu veidu intelektuālā īpašuma tiesību piederību un uzṇēmumu darbības rezultātiem. ${ }^{16}$ Latvijā intelektuālā īpašuma tiesības nav pietiekami plaši izpētītas, tiesiskais regulējums ir arhaisks, un to nav iespējams pilnvērtīgi izmantot mūsdienu situācijā. Būtu nepieciešams papildu izpēti veikt saistībā ar intelektuālā īpašuma tiesiskā regulējuma un tā praktiskās piemērošanas problēmu identificēšanu.

Ja atsevišķi analizē valstis, kas šobrīd tērē mazāk P\&A, un nošķir valstu grupu līdz 1,5\% izdevumiem P\&A, tad var redzēt Latvijas augsto sniegumu, jo ierobežota finansējuma apstākḷos spējam uzrādīt teicamus rezultātus attiecībā uz jaunu zināšanu radīšanu, kas ir aizsargātas ar patentu (5. attēls).

Patenti vien negarantē papildu ienākumus tautsaimniecībā. Ja ir patentētas jaunas zināšanas, tad ir jautājums, kas ar tām tiek tālāk darīts - vai tās tiek komercializētas. Kā tālāko rādītāju loǵiskajā ķēdìtē ir vērts aplūkot arī augsto tehnolog̣iju īpatsvaru kopējā eksportā, kas var būt viens no rādītājiem jauniegūto zināšanu komercializācijā. ${ }^{17,18}$

Analizējot izdevumu P\&A ietekmes saistību ar augsto tehnologiju eksportu, Eiropas valstu grupā paveras aina, kas apliecina ciešu sakarību (6. attēls).

13 Sierotowicz, T. (2015). Patent activity as an effect of the research and development of the business enterprise sectors in the countries of the European union. Journal of International Studies, 8(2), 101-113. Pieejams: https://doi.org/10.14254/2071-8330.2015/8-2/9 [skatīts 11.02.2021.]

14 Almeida, A., \& Teixeira, A. A. C. (2007). Does Patenting negatively impact on R\&D investment? An international panel data assessment. Working Papers (FEP) - Universidade Do Porto, (162), 1-39. Pieejams: http://search.ebscohost.com/login.aspx?direct=true\&db=bth\&AN=31174212\&site=ehost-live [skatìts 11.02.2021.]

15 Penner-Hahn, J., \& Shaver, J. M. (2005). Does international research and development increase patent output? An analysis of Japanese pharmaceutical firms. Strategic Management Journal, 26(2), 121-140. Pieejams: https://doi.org/10.1002/smj.436 [skatīts 11.02.2021.]

16 LETA. Pētījums: Intelektuālā īpašuma tiesības pozitīvi ietekmē uzṇēmēju ekonomisko situāciju. Delfi Bizness, 21.02.2021. Pieejams: https://www.delfi.lv/bizness/biznesa_vide/petijums-intelektuala-ipasuma-tiesibas-pozitivi-ietekme-uznemeju-ekonomisko-situaciju.d?id=52955787 [skatīts 06.02.2021.]

17 Meo, S. A., \& Usmani, A. M. (2014). Impact of R\&D expenditures on research publications, patents and high-tech exports among european countries. European Review for Medical and Pharmacological Sciences, 18(1), 1-9.

18 Priede, J., \& Pereira, E. T. (2013). Innovation as a key factor in the international competitiveness of the European Union. European Integration Studies, (7), 212-221. 
5. attēls. Sakarība starp Eiropas valstu izdevumiem pētniecībai un attīstībai (P\&A) līdz $\mathbf{1 , 5 \%}$ (\% no IKP - horizontālā ass) un patentu skaitu uz 1 miljonu iedzivotāju (pieteikti EPO - vertikālā ass) 2004.-2019. gadā

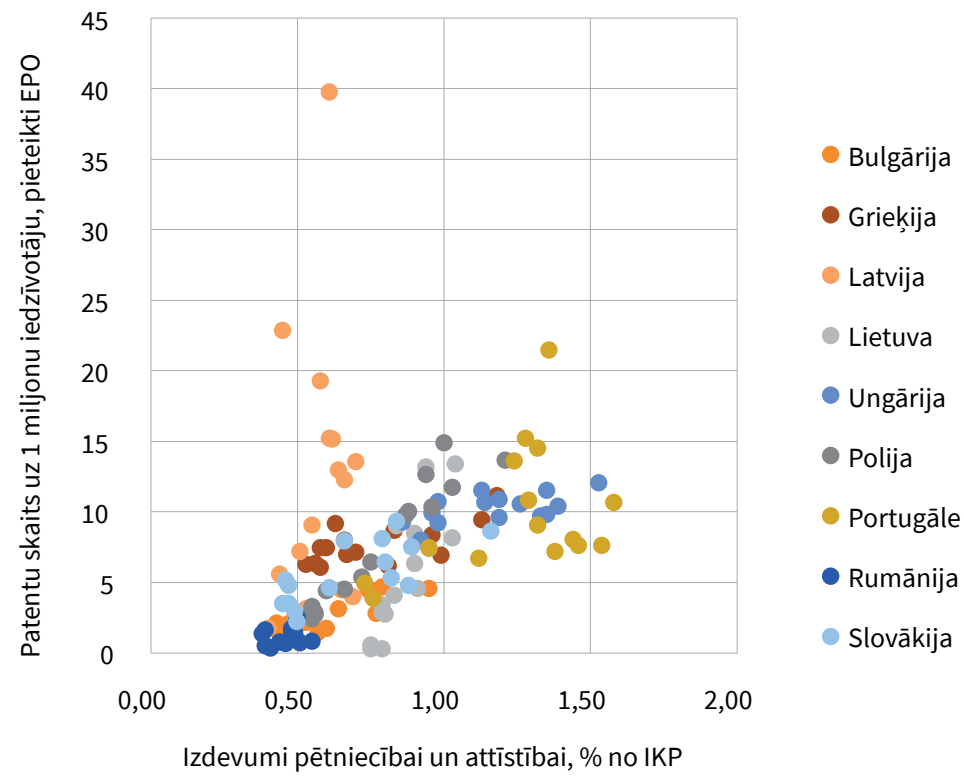

6. attēlā redzams sadalījums pa klasteriem, kas kopumā raksturo valstu grupu sniegumu. Ja ṇem vērā attēlā iezīmēto ass līniju, tad valstu, kas ir virs ass līnijas, sniegums augsto tehnologiju eksportā relatīvi ir augstāks attiecībā pret ieguldījumiem P\&A, un šajā ziṇā ir iespējams izcelt arī Latviju. Protams, globalizācijas apstākḷos ir jāṇem vērā produktu dzīves cikls un tas, ka ražošana ar laiku var tikt pārcelta uz citu valsti, kas attiecīgi var ietekmēt interpretāciju par šo datu ciešo sakarību.

Kopumā var secināt: kaut gan ES veicina dalībvalstu ieguldījumu P\&A, atbalsts no ES budžeta varētu būt lielāks, lai ES būtu spējīga veiksmīgi konkurēt pasaulē attīstīto valstu grupā. Papildu kopējam ES sniegumam svarīgs ir katras dalibvalsts sniegums.

Latvija arī ierobežota P\&A finansējuma apstākḷos spēj uzrādīt atzīstamu sniegumu, tomēr lielāka apjoma valsts budžeta P\&A finansējuma pieejamība veicinātu straujāku zinātnes un pētniecības potenciāla attīstību Latvijā, kas savukārt pozitīvi ietekmētu augstākas pievienotas vērtības radīšanas iespējas, kā arī augsto tehnologiju eksporta palielināšanos. 
6. attēls. Sakarība starp Eiropas valstu izdevumiem pētniecībai un attīstībai (P\&A)

(\% no IKP - horizontālā ass) un augsto tehnologiju eksportu

(\% no kopējā eksporta - vertikālā ass) 2007.-2018. gadā ${ }^{19}$

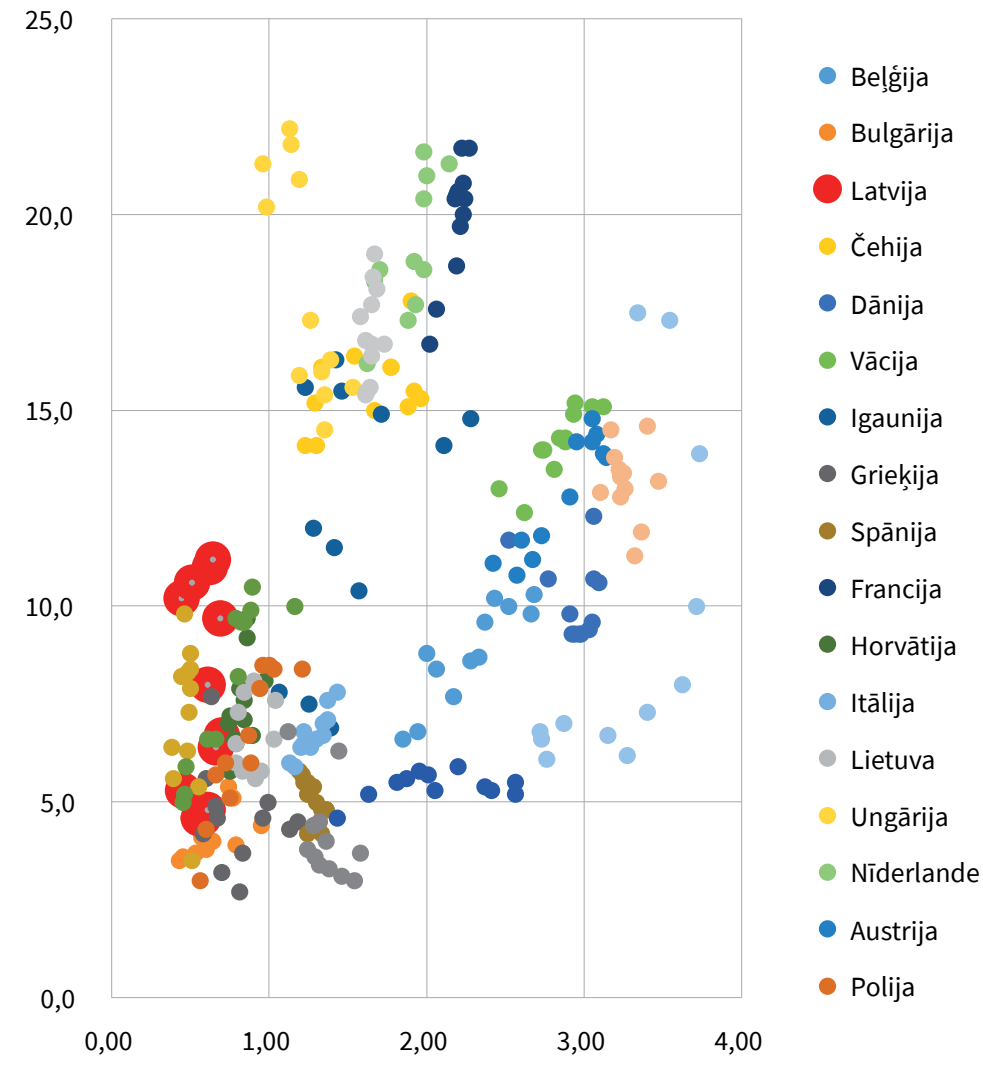

Avots: Eurostat.

Piemēram, Atveseḷošanas un noturības mehānisma ekonomikas transformācijas un produktivitātes reformai finansējums varētu būt aptuveni $10 \%$ no kopējā apjoma jeb aptuveni 165 milj. EUR, un ir paredzētas divas daļas:

- inovāciju un privāto investīciju P\&A veicināšana ( 82,5 milj. EUR);

- augstskolu pārvaldības reforma un cilvēkresursi (82,5 milj. EUR).

Iniciatīva veicināt privātā sektora pētniecības un inovāciju aktivitāti ir apsveicama, jo pēdējo 15 gadu laikā Latvijas uzṇēmumu ipatsvara tendence ir negatīva, tomēr iezīmētajam finansējumam ir jābūt daudz lielākam, lai Latvija spētu palielināt privātā sektora inovācijas spēju, pievienoto vērtību un labklājību. Ir

19 2021. gada 29. martā Eurostat nav pieejami aktuālāki dati. 
rekomendējams efektīivi izmantot arī inovāciju atbalstam paredzēto finansējumu no ES daudzgadu budžeta 2021.-2027. gadam.

Daži zinātnieki ir apgalvojuši, ka zemāki ES izdevumi P\&A galvenokārt ir saistīti ar ekonomikas struktūras efektu, proti, $P \& A$ intensīvas ražošanas un pakalpojumu nozares ir nepietiekami pārstāvētas ES ekonomikā salīdzinājumā ar Amerikas Savienotajām Valstīm..$^{20}$ Citi autori ir uzsvēruši iekšējā efekta esamību, norādot, ka ES uzṇēmumiem ir vispārējas grūtības panākt produktivitātes pieaugumu no ieguldījumiem pētniecībai un attīstībai. Saskaņā ar šo viedokli ES uzṇēmumiem katrā rūpniecības nozarē raksturīga zemāka P\&A intensitāte salīdzinājumā ar līdzīgiem uzṇēmumiem Amerikas Savienotajās Valstīs. Turklāt pētnieki apgalvo, ka ES uzṇēmumiem ir zemākas iespējas pārvērst $\mathrm{P} \& \mathrm{~A}$ ieguldījumus produktivitātes pieaugumā nekā ASV uzṇēmumiem.

Arī analizējot ES valstu atšķirības pa nozarēm, tiek identificēti iespējamie atškirību cēloṇi, proti, tehnolog̣iju līmenis vai sociālā un uzṇēmējdarbības vide dažādās valstīs atšķiras, kas noved pie atškiirīgām produktivitātes tendencēm katrā nozarē vai apvienojumā ar katras dalībvalsts augstu specializāciju konkrētās nozarēs noved pie atšķirīibām kopējā līmenī. ${ }^{21}$

Viena no zināmām īpatnībām ES ir vērojama saistībā ar izdevumiem P\&A un to struktūru. Ja lūkojas ne tikai uz kopējo izdevumu apjomu, bet arī uz izdevumu avotu, paveras interesanta aina (7. attēls).

Kā redzams 7. attēlā, tad Latvija ir unikālā situācijā ES kontekstā, jo aptuveni 75\% no visiem izdevumiem P\&A nāk no valdības sektora un augstākās izglìtības sektora, kas apliecina finansējuma avotu nozīmīgumu, kā arī pašas valdības nozīmi inovācijas spējas attīstišanā Latvijā. Vienlaikus jāṇem vērā tas, ka šī statistika var būt nepilnīga, jo tika iegūta informācija, ka uzṇēmumi Latvijā nepilnīgi aizpilda statistikas anketas attiecībā uz finansējumu, kas tiek ieguldīts pētniecỉbā un attīstībā.

Lìdzịgā situācijā (respektīivi, pietiekami liels valdỉbas un izglìīibas sistēmas izdevumu īpatsvars) ir arī Latvijas kaimiņvalstīs - Lietuvā (59\%) un Igaunijā (56\%). Augsts valdības un izglìtības sistēmas izdevumu īpatsvars ES ir arī Horvātijai - 52\%, Grieķijai - 50\%, Portugālei - 47\%, Slovākijai - 46\%. Kopumā var redzēt tendenci - jo lielāks kopējā finansējuma apjoms, jo lielāks biznesa sektora ieguldïjums kopējos P\&A izdevumos.

8. attēlā var redzēt Latvijas kopējos izdevumus P\&A sadalïjumā pa sektoriem (privātais bezpeḷnas sektors nav norādìts, jo Latvijai par to nav datu vai arī

20 Castellani, D., Piva, M., Schubert, T., \& Vivarelli, M. (2018). Can European productivity make progress? Intereconomics, 53(2), 75-78. Pieejams: https://doi.org/10.1007/s10272-018-0725-8 [skatīts 11.02.2021.]

21 Emvalomatis, G. (2017). Is productivity diverging in the EU? Evidence from 11 Member States. Empirical Economics, 53(3), 1171-1192. Pieejams: https://doi.org/10.1007/s00181-016-1161-x [skatits 11.02.2021.] 


\section{7. attēls. Eiropas Savienības valstu izdevumi pētniecībai un attīstībai (P\&A) pa sektoriem, \% no IKP, 2018. gads ${ }^{22}$}

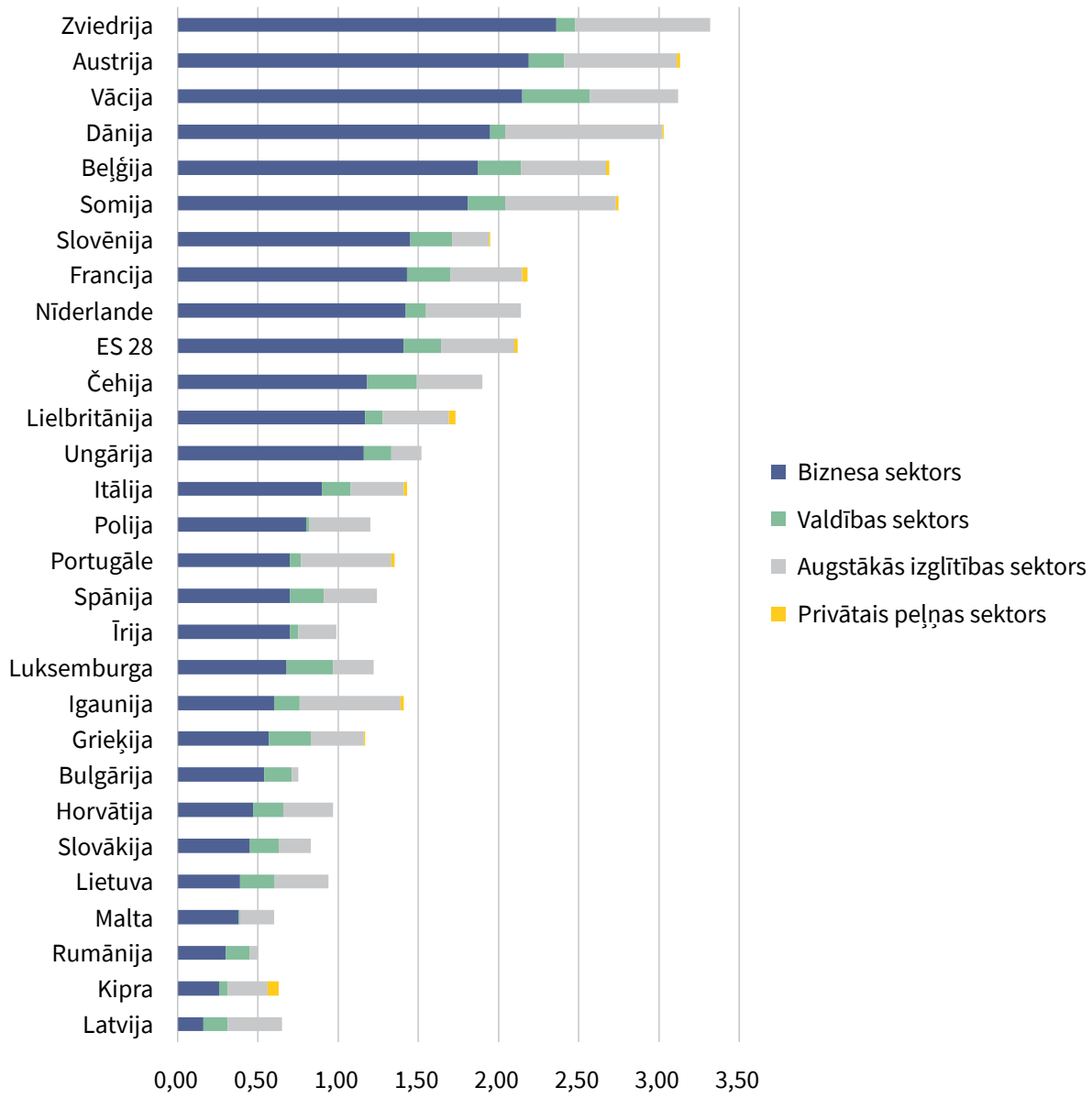

Avots: Eurostat.

vērtība ir 0). Dzeltenā līkne atsevišķ̧i norāda valdības un izglītības sektoru īpatsvaru kopējos izdevumos; kopš 2000. gada tas ir saglabājies nemainīgi augsts, izņemot 2006. gadu, kad bija vērojami ievērojamāki biznesa sektora ieguldijjumi.

Latvija ir unikālā situācijā ar izdevumu struktūru P\&A, kam ir virkne skaidrojumu, kas izriet no ekonomikas struktūras. Latvijā situācija parāda

22 2021. gada 29. martā Eurostat nav pieejami aktuālāki dati (tikai 6 valstīm ir provizoriskais novērtējums par 2019. gadu), tāpēc par ES nav pieejama informācija par 2019. gadu, un par Latviju informācija CSP ir citā griezumā. 


\section{8. attēls. Latvijas izdevumi pētniecībai un attīstībai (P\&A) sadalījumā pa sektoriem laikposmā no 2000. līdz 2018. gadam, \% no IKP (kreisā ass) un valdības un augstākās izglītības sektoru îpatsvars kopējos izdevumos \% (labā ass) ${ }^{23}$}

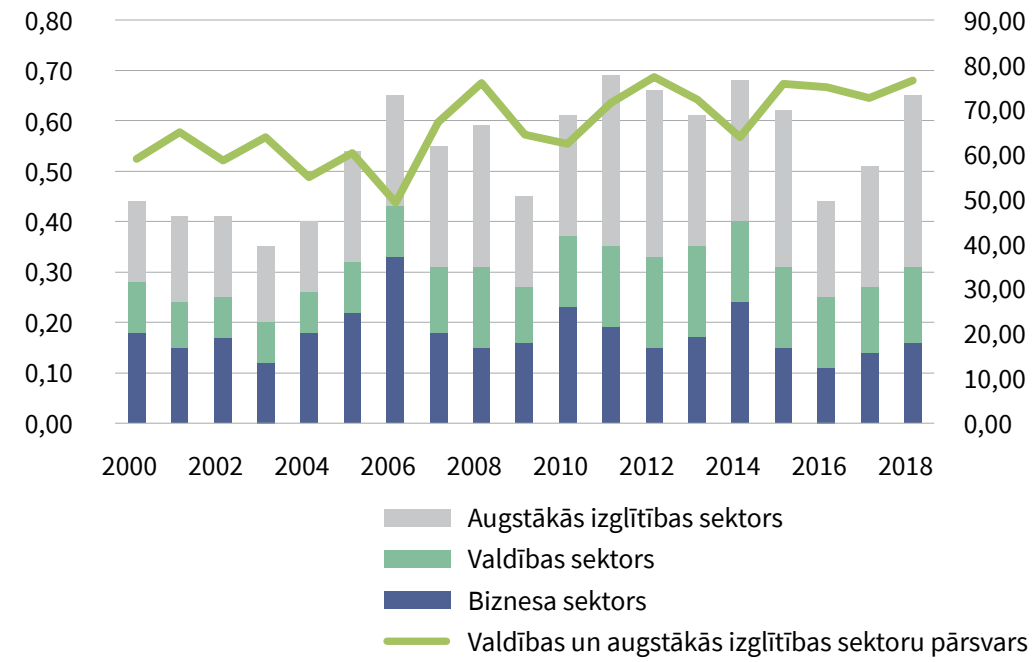

Avots: Eurostat

finansējuma avotu nozīmīgumu, kā arī pašas valdības nozīmi inovācijas spējas attīstišanā. Turklāt pētijumi apskata privātā un publiskā finansējuma P\&A mijiedarbību un to, kā tie viens otru var ietekmēt. ${ }^{24,25,26}$

\section{Starptautisko institūciju ieteikumi $P \& A$ veicināšanā}

Ieguldījumi P\&A ir vieni no būtiskākajiem konkurētspējas veicinātājiem, jo tieši ietekmē valstu potenciālu inovācijām un modernai konkurētspējai. Pasaules Ekonomikas foruma metodoloǵija "inovāciju pīlāru” paredz kā vienu no

23 2021. gada 29. martā Eurostat nav pieejami aktuālāki dati (tikai 6 valstīm ir provizoriskais novērtējums par 2019. gadu), tāpēc par ES nav pieejama informācija par 2019. gadu, un par Latviju informācija CSP ir citā griezumā.

24 Dinges, M., Berger, M., Frietsch, R., \& Kaloudis, A. (1997). Public versus private funded business R\&D: Sector specific specialisation indices as a tool for policy analysis.

25 Ishibashi, I., \& Matsumura, T. (2006). R\&D competition between public and private sectors. European Economic Review, 50(6), 1347-1366. Pieejams: https://doi.org/10.1016/j.euroecorev.2005.04.002 [skatīts 11.02.2021.]

26 Jyrki, A.-Y. (2005). Impact of Public R\&D Financing on Private R\&D does Financial Constraint Matter? European Network of Economic Policy Research Institutes, (30), 17. 


\section{9. attēls. Valstu (reǵionu) izdevumi pētniecībā un attīstībā (P\&A), \% no IKP}

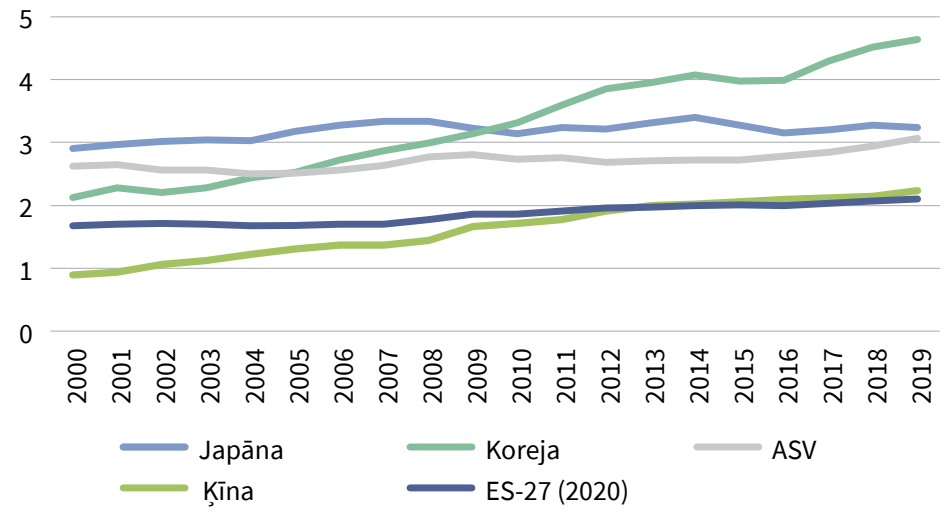

Avots: ESAO.

nozīmīgākajiem. Līdz ar to pasaules reǵgionu konkurence tiek skatīta arī pēc to spējas tālredzīgi atvēlēt līdzekḷus P\&A (9. attēls).

9. attēlā ir skaidri redzama konkurences cīṇa un attiecīgi arī valstu (reǵionu) ambīcijas, kas ES nav zudušas kopš Lisabonas stratēgijā paziṇotā mērḳa ${ }^{27}$ - kḷūt par konkurētspējīgāko reǵionu pasaulē. Lai to panāktu, ES sev ir definējusi mērķi - P\&A izdevumiem ir jāsasniedz 3\% no IKP. Jāteic, ka tas nav viegli īstenojams mērķis, ņemot vērā ES valstu atšķirīgo situāciju; piemēram, 2018. gadā 3\% no IKP sasniedza un pārsniedza tikai četrās ES valstis: Dānija - 3,03\%, Vācija - 3,12\%, Austrija - 3,14\%, Zviedrija - 3,32\%.

EK ekonomikas novērtējums Latvijai paredz, ka Covid-19 krīzes ietekmē IKP kritums 2020. gadā būs 3,5\% (atbilstoši CSP datiem IKP kritums 2020. gadā bija 3,6\%). 2021. gadā jau tiek prognozēts pieaugums 3,5\% apmērā, 2022. gadā 3,1\% apmērā. ${ }^{28}$ Var secināt, ka Covid-19 krīzes ietekmē Latvijas tautsaimniecība turpinās attīstīties, un svarīgi būs turpināt arī P\&A, tam paredzot attiecīgu finansējumu. ${ }^{29}$

Inovāciju veicināšanas nepieciešamībai Covid-19 krīzes laikā un pēc krīzes ir veltīts Ekonomiskās sadarbības un attīstības organizācijas (Organisation for Economic Co-operation and Development - OECD) pārskats "Zinātne, tehnologijas

\footnotetext{
27 Luksa, M. Lisabonas stratēǵija un tās mācības. LV portāls, 21.01.2010. Pieejams: https://lvportals.lv/ viedokli/203980-lisabonas-strategija-un-tas-macibas-2010 [skatīts 11.02.2021.]

28 European Commission. European Economic Forecast. Winter 2021 (Interim). Pieejams: https://ec.europa. eu/info/sites/info/files/economy-finance/ip144_en_1.pdf [skatìts 12.02.2021.]

29 Turpat.
} 
un inovācijas"30 (OECD Science, Technology and Innovation Outlook 2021). Pārskata autori norāda, ka pētniecỉbas un inovāciju sistēmas ir spēlējušas nozīmīgu lomu, lai veiksmīgi cīnītos ar Covid-19. Inovāciju atbalsta sistēmas ir jāstiprina, lai tās būtu efektīvas arī nākotnes izaicinājumu priekšā. Covid-19 krīze ir veicinājusi starptautisko sadarbību zinātnes, tehnologiju un inovāciju (ZTI) jomā un paplašinājusi atklātas piekḷuves izpēti un digitālo rīku izmantošanu. Covid-19 ietekmē arī tiek pārskatītas ZTI politikas, tās fokusējot uz ilgtspējỉbu, iekḷaušanos un noturību. Pārskatā izdarīi šādi galvenie secinājumi:

1. ZTI sistēmas reakcija uz Covid-19 krīzi bija izlēmīga, operatīva un nozīmīga gan publiskajā, gan privātajā sektorā.

2. Starptautiskajai sadarbībai bija izšķiroša loma pētniecības un inovāciju reakcijā uz Covid-19.

3. Uzñēmumu novatoriskais potenciāls tika izmantots, lai rastu risinājumus dažādām krīzes situācijām.

4. Uzñēmumi vairākos sektoros ir samazinājuši savas investīcijas pētniecībā un inovācijās.

5. ZTI politikas virzieni ir jāpārskata, lai tās būtu vērstas uz ilgtspējību, iekḷaujošu sabiedrību un noturību.

Latvijas produktivitātes ziņojumā 2020 secināts, ka, gudri investējot konkurētspējas un produktivitātes veicināšanā, sākot no 2022. gada, var nodrošināt ekonomikas izrāvienu, IKP pieauguma tempam gada vidēji sasniedzot ap 5\%.

\section{Secinājumi}

Latvijai kā valstij ar mazu ekonomiku ir kritiski svarīgi specializēties un veikt ieguldījumus tajās $P \& A$ jomās, kurās Latvijā ir:

- zinātniskā izcilība;

- tehniskie speciālisti un infrastruktūra;

- tradīcijas un kapacitāte ātrai izaugsmei;

- eksporta niša produktiem un pētniecíbas pakalpojumiem.

Starptautiskā pieredze pierāda, ka sekmīga un efektīva inovācija, īpaši krīzes apstākḷ̆os valstīs ar mazu iekšējo tirgu (mazu ekonomiku), pie kurām pieder arī Latvija, nav iespējama bez valsts un pašvaldību finansiālā atbalsta. It īpaši tas attiecināms uz publiski pieejamas inovāciju infrastruktūras izveidi, jo mazajās valstīs ir salīdzinoši maz lielo uzṇēmumu, kas spētu veidot savus privātos P\&A centrus ar tehnolog̣iju pārnesei un inovācijai nepieciešamo infrastruktūru.

30 OECD iLibrary. OECD Science, Technology and Innovation Outlook 2021. Pieejams: https://www.oecdilibrary.org/science-and-technology/oecd-science-technology-and-innovation-outlook-2021_75f79015-en [skatīts 16.01.2021.] 